\title{
Language Learning Motivation among Malaysian Pre-University Students
}

\author{
Muneera Muftah ${ }^{1} \&$ Shameem Rafik-Galea ${ }^{2}$ \\ ${ }^{1}$ Department of English, Faculty of Modern Languages and Communication, Universiti Putra Malaysia, Malaysia \\ ${ }^{2}$ Office of Marketing and Communication, Administration Building, Universiti Putra Malaysia, Malaysia \\ Correspondence: Dr. Muneera Muftah, Department of English, Faculty of Modern Languages and \\ Communication, Universiti Putra Malaysia, 43400 UPM Serdang, Selangor D. E., Malaysia. Tel: 603-8946-8944. \\ E-mail: muneeramuftah@yahoo.com
}

Received: December 19, 2012 Accepted: February 6, 2013 Online Published: February 22, 2013

doi:10.5539/elt.v6n3p92 URL: http://dx.doi.org/10.5539/elt.v6n3p92

\begin{abstract}
The study describes and examines Malaysian pre-university students' integrative and instrumental motivation toward learning English language. In this study, 182 non-English major students in one of the Malaysian public universities are selected to fill out a questionnaire reflecting their attitudes and motivation towards learning English. The findings indicate that Malaysian pre-university students have very high motivation and positive attitudes towards leaning English and that they are more instrumentally motivated. Based on the findings some suggestions and recommendations for teachers have been highlighted.
\end{abstract}

Keywords: attitude, integrative motivation, instrumental motivation, Malaysian pre-university students

\section{Introduction}

Motivation is a complicated psychological process. It starts with a need and leads to a behavior that helps move people towards achieving their goals (Melendy, 2008). It is also believed to be an uplifting non-intellectual factor that raises people's eagerness, willingness, and happiness to do and learn things, and, of course, learning English is no exception. The different approaches to figure out this complexity and ultimately comprehend the issue of student motivation are worthwhile as they can assist teachers to predict and influence the students' behavior positively. Therefore, students' motivation to learn a language has been long investigated, particularly, in the domain of second language acquisition (SLA). In SLA, Dornyei (1994) has claimed that motivation refers to an individual attempt and desire to learn a specific language and his/her positive attitudes toward learning it.

It is also true that motivation is considered to be one of the strong predictors driving language learning success (Paula M. Winke, 2005, Vol. 9), as opposed to the early believe that suggest cognitive abilities to be the core factor for successful language learning. A number of studies including those carried out by Gardner and his colleagues have argued that language learning motivation is a key factor of successful language learning (see e.g. Masgoret and Gardner (2003) for more reviews of this literature). Accordingly, motivated students would be more eager and enthusiastic to devote the time required to language learning. Moreover, having a specific goal and desire to learn a language aids students put forth their best effort and maintain their motivation. Guilloteaux and Dörnyei (2008) further contend that students' degree of motivation is another major issue that researchers need to shed some light on. Generally speaking, a comprehensive understanding of students' motivation to language learning can help teachers to abundantly increase students' achievement and long-term persistence in learning.

Basically, learners have several reasons for studying a second language (L2). They may either study a language for specific reasons or have a special affinity for the target language and its community. Teachers, on the other hand, are often very aware of the advantages that learning a second language as well as language proficiency can bring in terms of career, but to many language learners, studying the language is only a language requirement fulfilled to obtain an academic degree.

Since the appearance of the seminal work of Gardner and Lambert in 1972, language teachers and researchers have started to realize the central role that motivation plays in language learning. Gardner and Lambert have established the most commonly used framework for understanding the different attitudes and motivation that language learners typically have. Gardner's (1985) particular, quite narrow, use of the term motivation has 
required clarification, which Masgoret and Gardner (2003) provided by distinguishing between orientations and motivation. Masgoret and Gardner have contended that motivation is mainly goal-directed behavior, revealed in a variety of more specific behaviors and cognitions that serve as the manifestations of motivation. Motivation in this sense is operationalized as the sum of motivational intensity; desire to learn the target language, and attitude toward learning the target language. These concepts are closely related to the actual amount of effort, the desire to attain a high and satisfactory level of competence, and that effect experienced while learning the language. In Gardner's socio-educational model, this factor rather than orientations, is most directly related to achievement.

Orientation, on the other hand, refers to the intention of learning an L2, which is recognized as: integrative and instrumental. Learners who are integratively motivated actually have their own reasons to integrate into the target language community. They have personal affinity for people speaking a particular language. They learn a language because they are interested to better understand and get to know the native speakers of that language and their culture, etc. In contrast, Learners who are instrumentally motivated have no intention to integrate with the L2 community, rather, they have different reasons for learning a second language that "reflect the more utilitarian value of linguistic achievement," (Gardner's, 1985: 267). They learn a language, for instance, to get into university, to fulfill a university language requirement or get a salary bonus etc.

According to Gardner and Lambert (1972), integrative orientation appears to be superior to instrumental orientation in SLA. In particular, literature review has shown that integrative motivation might reduce anxiety (Wei, 2007) and that motivational practice of the teachers could help uplift the motivation of the students (Guilloteaux and Dörnyei, 2008). However, there is no clear cut agreement among the language learning researchers on the superiority of one type of motivation or orientation over the other. The findings of some studies on language learning motivation have even contradicted that of a previous study on a similar subject in the same context (Lamb, 2007). Some other studies have exclusively aimed at describing the motivational patterns of the participants rather than proving whether certain kinds of motivation can guarantee success in learning English as a second language (ess e.g., Rahman, 2005; Chen et al., 2005).

It has also been revealed that language learners could potentially be motivated by using the meta-cognitive language learning strategies, and that strategy use might be associated with integrative motivation, rather than instrumental motivation (Wu Man fat, 2007). In addition, it was found that the classroom atmosphere might be positively correlated with the language learners' motivation ( $\mathrm{Wu}$ and $\mathrm{Wu}, 2008)$.

Language learning researchers have relied on Gardner's theory of attitudes and motivation to present a clear understanding of motivation by providing some major distinctions between motivation and orientation, and finding out logical interpretations to compare their own research findings (for more detailed examples see Babaee, 2012). Although numerous research studies have been conducted on motivation in SLA within the past ten years, most of these studies that have been done in Asia such as in China and Hong Kong (Liu, 2007; Wang, 2007; Wei, 2007; Wu Man fat, 2007; Yihong et al., 2007) and others in South Asia (Rahman, 2005), Southeast Asia (Lamb, 2007), Southwest Asia (Balkir and Topkaya, 2009), or East Asia (Guilloteaux and Dörnyei, 2008; Melendy, 2008; Wu and Wu, 2008; Takase, 2007; Chen et al. 2005).

Basically, most of the studies that have been conducted in Southeast Asia are done in Indonesia. Countries such as Malaysia, where the present study is carried out, is still noticeably under-researched when it comes to the investigation on second language learning motivation. The motivation theory and the permanent focus on motivation in SLA, remain constantly significant regardless of contemporary educational issues (Wei, 2007). Therefore, more research is required in this area due to the important role that motivation plays on SLA, particularly, in the Malaysian context where English is used as a second language to obtain a better understanding of the students' integrative and instrumental motivation and attitudes towards English language learning.

\section{English Language Use in Malaysia}

Malaysia has experienced several shifts in language policy as the government has had to confront the challenge of unifying a multilingual society. At the outset, the official language status and the use of language in all government functions and sectors and as the medium of instruction at all levels have shifted to Bahasa Melayu after its independence in 1957 (Gill, 2002). However, the English language has played the role of a second official language in Malaysia.

English language usage became more important when the Malaysian Government started its three concrete plans for creating a fully developed nation by the year 2020. These plans include the development of the country into an industrialized nation in line with vision 2020, the establishment of the multimedia super corridor (MSC) and 
the establishment of Malaysia as a regional centre of education. With such plans the Government has been urged to adjust its language policy and English plays a very important role since Malaysia needs English proficient people and needs to allow English to play a more dominant role (Asmah, 1997; Mansor, 1997). Accordingly, the role of the English language is rapidly expanding from being the language for education and official records to being a tool of communication in different circumstances.

A radical change in language policy, from Bahasa Malaysia, the national language to English, has also been established for different aspects of knowledge, science and technology at different levels of the educational system due to the fact that ample sources of knowledge, science and technology are written in English, and along the lines of the education policy; English is taught as a second language. In 2003, for instance, the medium of instruction shifted to English for teaching the subjects of maths and science. This entailed a change in the language of education in Malaysian schools (both national and national-type schools). Accordingly, language use has shifted from Bahasa Malaysia, the national language, to English in the national schools and from the language of community, Mandarin and Tamil to English in the national-type schools.

Bearing in mind these different environments, English is placed and taught as the second language in Malaysia (Gill, 2002). Studies (Ainol Madziah and Isarji, 2009; Samsiah, et al., 2009; Thang, 2004) have shown that Malaysians have realized the importance of being competent in English to be able to achieve their future goals and that students are integrative and instrumental motivated to improve their English competency. However, being motivated to learn English doesn't give us any clue that the students are competent in English. This could be due to the fact that most of the studies that have been done in this regard are undertaken in tertiary settings. Studies at the university level have identified various problems with pre-university and/or undergraduate students in terms of English language learning. There is a possibility that secondary school students are still not fully aware of the importance of learning English for their future endeavors and are just not motivated enough to learn English. The present study intends to investigate these issues further by carrying out a questionnaire survey on a group of pre-university/foundation students in a selected university to examine their attitude, integrative and instrumental motivation toward learning English as a foreign language. The primary aim of this study is to obtain a better understanding of the students' motivation and attitudes toward the English language learning processes in this university. This goal will be achieved through addressing the following research objectives:

1. To determine the extent to which the pre-university students are instrumentally or integratively oriented towards English language learning.

2. To identify whether or not pre-university students' attitudes and motivation for learning English have changed after entering university.

\section{Methodology}

\subsection{Participants}

A total of one hundred eighty two (182) pre-university/foundation non English major students (135 females \& 47 males) from a selected university in Malaysia participated in this study. The selected university is a public university located in Klang Valley on the west coast of Peninsular Malaysia. The participants are from different academic majors. The fact that all volunteer participants are recruited from different majors in the university helps provide a variety of views about their second language learning, attitudes as well as motivation.

The study involves participants from different ethnic, cultural, religious and linguistic backgrounds with their ages ranging from 17 to 20 years. The number of the foreign languages that the participants speak ranged from one to more than three languages. These languages included English, Arabic, Mandarin, Korean, Tagalog, Toraja, Duson, Japanese, French, Spain, Hangul, and Cantonese. With regard to the English language, most of the students (149 students) learnt English in primary school and some learnt the language at home and outside schools. They continued to learn English in secondary school and at the pre-university level. Their interaction with foreign visitors outside the classroom is low with an overall mean score of 3.297. The overall interaction with foreigners ranged from seldom to sometimes (39.61\% and $45.1 \%$ respectively). That is to say, most learners had very little contact with English outside the classroom and in most cases no contact at all. (See Table 1 for the distribution of the participants). 
Table 1. Distribution of the Participants

\begin{tabular}{llll}
\hline Category & Sub-category & Frequency $(\mathbf{N = 1 8 2})$ & Percentage (\%) \\
\hline Gender & Male & 47 & 25.8 \\
Age & Female & 135 & 74.2 \\
& $17-20$ years & 182 & 100.0 \\
& $21-25$ years & - & 00.0 \\
Ethnicity & 26-30 years & - & 00.0 \\
& above 30 years & - & 00.0 \\
& Malay & 166 & 91.2 \\
Mother Tongue & Chinese & 6 & 3.3 \\
& Indian & 7 & 3.8 \\
& Others & 3 & 1.6 \\
Foreign language they & Malay & 168 & 92.3 \\
speak & Mandarin & 6 & 3.3 \\
& Tamil & 7 & 3.8 \\
& English & 1 & .5 \\
& Non & 16 & 8.8 \\
Learned English & One & 105 & 57.7 \\
language & Two & 46 & 25.3 \\
& Three & 44 & 6.0 \\
& More than three & 4 & 2.2 \\
Learning English at & At school & 149 & 81.9 \\
Interaction with foreign & Outside school & 5 & 2.7 \\
visitors & At his/her University & 23 & 12.6 \\
& At another University & 4 & 2.2 \\
& Others & 1 & .5 \\
& My university & 180 & 98.9 \\
& Another university & 2 & 1.1 \\
& Very often & 5 & 2.7 \\
& Often & 18 & 9.9 \\
& Sometimes & 82 & 45.1 \\
& Seldom & 72 & 39.6 \\
& Never & 5 & 2.7 \\
\hline
\end{tabular}

\section{Data Collection Procedures}

The English version of the Attitude/Motivation Test Battery (AMTB) 7-point Likert Scale format, originally developed by Gardner (2004) along with Clement et al.'s (1994) 7-point Likert Scale format were adapted to a 5-point scale, ranging from 'Strongly Disagree' to 'Strongly Agree'. Gardner's AMTB is reported to have a good reliability and validity (Gardner, 1985, 2005; Gardner and Macintyre, 1993). The literature also shows that the AMTB has been used in many studies of L2 motivation (e.g., Baker and Macintyre, 2000; Masgoret, Bernaus, and Gardner, 2001, among others).

The original instrument comprising of over 130 items is adapted to the Malaysian context following the recommendations put forth by both Gardner (personal communication, October 16, 2008) and Dörnyei (2001) who suggest adjusting instruments to the context where they are going to be used. Gardner himself has advised researchers who are going to adapt his instrument to make sure to adapt the items carefully so that they measure what they are supposed to measure.

In the context of the present study, the adaptation of the AMTB implies the following:

- Negatively keyed items are eliminated to prevent students'confusion (Brown and Rodgers, 2002).

- The subscale about parental motivation is eliminated because all of the participants recruited were older than 17 compared to the original version of AMTB which was designed for grade 11 Canadian students (Gardner, 1985).

- The scale about anxiety is also eliminated because this is beyond the scope of this study. 
- According to Dörnyei's (2001) suggestion to adjust scales if they going to be used in contexts other than where it was developed, all other items are considerably adjusted and adapted to fit into the Malaysian context

- The items which are designed to assess the performance of teachers, course evaluation items, subscales which are included in the first part of the AMTB in a more general format and items which are semantically different are all eliminated.

The final version of the instrument includes 3 sections:

- Section A (background information): This section was designed to elicit information on demographic and educational profile of the participants.

- Section B (language self efficiency): It consists of three open-ended questions in two parts. The first one (i.e. Part1) is constructed to measure the participants' English language self efficacy or their perception as learners by requesting them to rate their own English proficiency level from poor to excellent so as to indicate how proficient they are at English. The qualitative data is derived from the second and third open-ended questions (i.e. Part 2). Question 2 is aimed to determine if the students' motivation towards learning English has changed after entering the university as well as the reasons that motivate them. Question 3 is generated for the participants to identify the main reasons why learning English is so important to them. In other words, are the students motivated integratively or instrumentally in learning English?

- Section C (English-learning motivation scale): This section comprises the final version of the AMTB used for this study. It consists of 3 parts that measure the following subscales:

$>$ Part 1 (instrumental orientation and motivational intensity): On this scale, 19 items (items 1-19) are planned to measure the participants' utilitarian reason(s) for learning English.

$>$ Part 2 (Integrative orientation and attitudes toward English-speaking people): this scale includes 12 items (items 20-31) that would show the learners' integrative orientation towards the target language and their attitudes toward English-speaking people.

$>$ Part 3 (Attitudes towards learning English: this scale includes 5 items (items 31-36, see Appendix) that would measure the participants' attitudes towards learning English.

The purpose and reasons for undertaking a research on L2 motivation and different terms used are explained to the students by their instructors before the distribution of the questionnaire. During the completion process of data collection, the instructors are requested to help the students to understand all sections and all different parts and subscales of the questionnaire. Students are also assured that the information they give would be kept confidential and be used for research purposes only.

\section{Results and Interpretation}

The students are firstly asked to rate their English proficiency on a scale ranging from poor to excellent. The analysis of the results of perceived English proficiency (see Table 2) shows that 113 students (62.1\%) perceived their English to be average while 32 students (17.6\%) have rated themselves to be good in English and only 29 students $(15.9 \%)$ have perceived their English to be fair. That is to say, their high motivation might be in one way or another related to their perceived linguistic proficiency.

Table 2. Students' perceived levels of English Proficiency

\begin{tabular}{cccccccc}
\hline Item & $\mathbf{1}$ & $\mathbf{2}$ & $\mathbf{3}$ & $\mathbf{4}$ & $\mathbf{5}$ & \multirow{2}{*}{ M } & SD \\
\cline { 2 - 6 } & \multicolumn{7}{c}{$(N=182)$} \\
\hline Ability to speak English & 5 & 29 & 113 & 32 & 3 & 2.995 & .7168 \\
& $(2.7 \%)$ & $(15.9 \%)$ & $(62.1 \%)$ & $(17.6 \%)$ & $(1.6 \%)$ & & \\
\hline
\end{tabular}

$1=$ poor, $2=$ fair, $3=$ average, $4=$ good, $5=$ excellent, $\mathrm{M}=$ mean, $\mathrm{SD}=$ std.deviation

\subsection{Analysis of the Open-Ended Questions}

Today English plays an important role in our daily life. English is also widely used by students. One of the important aspects of language use is how the students themselves feel about the importance of speaking English. 
Among the students participated in this study, $40.1 \%$ "agree" and 39.6\% "strongly agree" that speaking English is very important. In comparison $2.2 \%$ of the students "disagree" and $2.7 \%$ "strongly disagree", that speaking English is important. Although, however, differences in levels of agreement and disagreement are observed, there is an uncertainty among some of the students $15.4 \%$ about the importance of speaking the language.

Table 3. Importance of Speaking English

\begin{tabular}{cccccccc}
\hline \multirow{2}{*}{ Item } & $\mathbf{1}$ & $\mathbf{2}$ & $\mathbf{3}$ & $\mathbf{4}$ & $\mathbf{5}$ & \multirow{2}{*}{ M } & SD \\
\cline { 2 - 6 } & \multicolumn{7}{c}{$(N=182)$} \\
\hline Importance to speak English & 5 & 4 & 28 & 73 & 72 & 4.115 & .9360 \\
& $(2.7 \%)$ & $(2.2 \%)$ & $(15.4 \%)$ & $(40.1 \%)$ & $(39.6 \%)$ & & \\
\hline
\end{tabular}

$1=$ strongly disagree, $2=$ disagree, $3=$ neither agree nor disagree, $4=$ agree, $5=$ strongly agree, $\mathrm{M}=$ mean, $\mathrm{SD}=$ std.deviation

Results of the open-ended question displayed that the majority of the students $(81.3 \%)$ have actually become more motivated to learn English (see Table 4). Most of them believe that they were less motivated to learn English at school level and that their motivation has increased because they have realized the importance of English for becoming more successful in their learning, especially for using internet search and finding scientific sources concerning their majors and studying reference books and journals.

Table 4. Students' Motivation towards Learning English after Entering the University

\begin{tabular}{ccccc}
\hline Item & & $\begin{array}{c}\text { Number }(\boldsymbol{N}=\mathbf{1 8 2}) / \\
\text { Percentage }(\%)\end{array}$ & M & SD \\
\hline Motivation to learn English: & $\begin{array}{c}\text { more motivated } \\
\text { less motivate }\end{array}$ & $\begin{array}{c}148(81.3 \%) \\
34(18.7 \%)\end{array}$ & 1.187 & .39084 \\
\hline
\end{tabular}

$\mathrm{M}=$ mean, $\mathrm{SD}=$ std.deviation

The pre-university students have mentioned different reasons why they are more motivated to learn English than when they were secondary school students. Basically, the contact hours in the school were only at the time they studied the English subject but in university, although the students met for few hours a week, they themselves did self-reading and searching where needed to prepare for assignments, written reports, presentations, papers or any other kind of activities, all of which required research, reading and writing in English. Some of other reasons are presented below:

\subsubsection{Instrumentality}

I am more motivated to learn English because:

- It is fun and more challenging in university than it was in school.

- In school we learn basic grammars of English while in the university we practice it.

- Lecturers' English language in the university is awesome.

- University lecturers are good in teaching English.

- I have realized that leaning English is important to pursue with my study.

- In the university settings, everything is taught in English.

- English is the most dominant international language and learning it helps me to do instant searches and enables me to use the computer programs more effectively.

- I am more motivated to learn English in order to use internet.

- There are a lot of assignments, power point presentations and different activities which require proficiency in English.

- The atmosphere in University requires us to be able to speak \& communicate in English.

- To get a job and to be able to communicate with foreigners. 
- Few of the pre-university students have a clear plan for going abroad for further education and for their future career.

- To get ready for job interviews which were usually done in English.

- I can speak with international students as much as I can.

- I would like to write essays in English as writing essays is challenging.

- I am more motivated to pass exams.

- I am more motivated to increase my knowledge.

- Leaning English will make me feel more confident and knowledgeable.

- I was motivated to learn and speak English by my friends who are proficient in language.

- I want to compete with other students who are excellent.

- I am dreaming to go overseas.

\subsubsection{Integrativeness}

\section{I am more motivated to learn English because:}

- I can make more friends and talk to internet friends from different parts of the world.

- I am interested to understand English movies and songs.

- I can interact with international students and foreigners comfortably.

Only $18.7 \%$ of the pre-university students have reported that they are less motivated to learn English after they have entered the university mainly because of the heavy burden of their study, time limitation and bad English learning atmosphere. Among other reasons why the pre-university students are less motivated to learn English are:

\section{I am less motivated to learn English because:}

- It is boring subject.

- I am not confident to speak English.

- Learning English is not fun.

- I don't have enough vocabulary to speak English.

- I am not interested to learn English, just to pass Exams.

- I have to learn basic grammars all over again.

- Most of the students speak Malay in and outside class.

- The teacher didn't encourage us to speak English in class.

\subsection{Analysis of the Instrumentality, Integrativeness and Attitudes Items}

the frequency distribution and mean scores of the instrumental orientation and motivational intensity items represented in Table 5 reports that questions Q1-Q12 and Q15-Q18 with the mean scores above 4 and questions number Q13, Q14 and Q19 with the mean scores approximately 4 indicate the students' high motivation with an overall mean score of 4.318 . The overall results show that most of the pre-university students have a very high instrumental motivation toward learning English as a foreign language (see Table 5). The questions which have the highest mean scores including Q1, Q4, Q5, Q6, Q7, Q16 and Q17 concern getting a good job, their future career, making a person more knowledgeable, give them a chance to work globally as well as show the students' need to understand English-speaking films, videos, TV/ radio and their need to read English books and to communicate. The results seem to show that the students are instrumentally motivated $(M=4.318)$ but they still have a higher degree of integrative motivation $(M=4.067)$ toward learning English. 
Table 5. Descriptive Statistics of Instrumental Orientation and Motivational Intensity ( $\mathrm{n}=182)$

\begin{tabular}{|c|c|c|c|c|c|c|c|}
\hline Items & 1 & 2 & 3 & 4 & 5 & $\overline{\mathbf{M}}$ & SD \\
\hline 1Q & 4 & 1 & 2 & $\begin{array}{l}46 \\
72\end{array}$ & $\begin{array}{c}129 \\
67\end{array}$ & $\begin{array}{l}4.621 \\
4060\end{array}$ & $\begin{array}{r}.7464 \\
9174\end{array}$ \\
\hline $3 Q$ & 1 & 1 & 20 & 75 & 85 & 4.330 & .7367 \\
\hline $4 Q$ & 0 & 3 & 4 & 56 & 119 & 4.599 & .6206 \\
\hline 50 & 1 & 1 & 7 & 59 & 114 & 4.560 & .6515 \\
\hline $6 \mathrm{Q}$ & 0 & 1 & 5 & 59 & 117 & 4.604 & .5734 \\
\hline $7 Q$ & 2 & 1 & 14 & 51 & 114 & 4.506 & .7562 \\
\hline $8 Q$ & 0 & 5 & 30 & 71 & 76 & 4.198 & .8104 \\
\hline $9 Q$ & 2 & 5 & 13 & 54 & 108 & 4.434 & .8301 \\
\hline $10 Q$ & 2 & 8 & 34 & 78 & 60 & 4.022 & .8917 \\
\hline 11Q & 0 & 3 & 21 & 71 & 87 & 4.330 & .7441 \\
\hline $12 Q$ & 0 & 4 & 42 & 67 & 69 & 4.104 & .8311 \\
\hline $13 Q$ & 1 & 9 & 47 & 62 & 63 & 3.973 & .9250 \\
\hline 14Q & 7 & 9 & 42 & 60 & 64 & 3.907 & 1.060 \\
\hline $15 Q$ & 0 & 2 & 12 & 69 & 99 & 4.456 & .6696 \\
\hline 160 & 0 & 2 & 4 & 59 & 117 & 4.599 & .5933 \\
\hline $17 Q$ & 1 & 3 & 5 & 59 & 114 & 4.550 & .6855 \\
\hline $18 Q$ & 4 & 0 & 9 & 9 & 100 & 4.434 & .7821 \\
\hline \multirow[t]{2}{*}{$19 Q$} & 4 & 17 & 50 & 59 & 52 & 3.758 & 1.039 \\
\hline & & & & & & 4.318 & \\
\hline
\end{tabular}

$1=$ strongly disagree, $2=$ disagree, $3=$ neither agree nor disagree, 4=agree, 5=strongly agree, $\mathrm{M}=\mathrm{mean}, \mathrm{SD}=$ std.deviation

On the other hand, the mean scores of culture questions on integrative orientation and attitudes toward English-speaking people as illustrated in Table 6 shows that the pre-university students were strongly motivated in questions Q20, Q21 and Q27. English is important to them because it allows them to be more at ease with other people who speak English. It is used as a mean of communication as it allows the students to meet and converse with more and varied people. Other questions including Q22-Q26, Q28 and Q29 show that the students are moderately motivated (see Table 6). In comparison to other questions, Q30 (the British are kind and friendly) and Q31 (the Americans are kind and cheerful), with mean scores of 3.346 and 3.324 respectively, show low level of integrative motivation. The overall mean score of students' integrative motivation $(M=4.067)$ indicate that they have quite high integrative orientation and attitudes toward English-speaking people. Generally, the students agree that studying English is important to them to interact with other English speakers and to meet various cultures and people. However, they seem to be neutral in viewing British and Americans as kind and friendly people. It might be due to their lack of contact with English native speakers.

Table 6. Descriptive Statistics of Integrative Orientation and Attitudes Toward English-Speaking People ( $\mathrm{n}=182)$

\begin{tabular}{lccccccc}
\hline Items & $\mathbf{1}$ & $\mathbf{2}$ & $\mathbf{3}$ & $\mathbf{4}$ & $\mathbf{5}$ & $\mathbf{M}$ & SD \\
20Q & 0 & 2 & 9 & 62 & 108 & 4.525 & .6461 \\
21Q & 0 & 0 & 10 & 73 & 99 & 4.489 & .6015 \\
22Q & 0 & 2 & 33 & 71 & 76 & 4.214 & .7748 \\
23Q & 0 & 3 & 22 & 82 & 75 & 4.258 & .7315 \\
24Q & 0 & 3 & 36 & 73 & 70 & 4.154 & .7926 \\
25Q & 3 & 7 & 35 & 74 & 63 & 4.028 & .9190 \\
26Q & 5 & 2 & 60 & 61 & 57 & 3.863 & .9506 \\
27Q & 0 & 3 & 16 & 60 & 103 & 4.445 & .7243 \\
28Q & 2 & 3 & 16 & 94 & 67 & 4.214 & .7604 \\
29Q & 2 & 3 & 49 & 78 & 50 & 3.940 & .8420 \\
30Q & 8 & 20 & 81 & 47 & 26 & 3.346 & 1.001 \\
31Q & 10 & 15 & 90 & 40 & 27 & 3.324 & 1.008 \\
& & & & & & 4.067 &
\end{tabular}

$1=$ strongly disagree, $2=$ disagree, $3=$ neither agree nor disagree, 4=agree, 5=strongly agree, $\mathrm{M}=\mathrm{mean}, \mathrm{SD}=$ std.deviation 
The descriptive statistics of attitudes towards learning English as presented in Table 7 show that the students have positive attitudes towards learning English with mean scores ranging from 3.879 to 4.209. In general, the students enjoy learning English. They like the atmosphere of their English classes. They further find learning English interesting.

Table 7. Descriptive Statistics of Attitudes Towards Learning English ( $\mathrm{n}=182)$

\begin{tabular}{llllllll}
\hline Items & $\mathbf{1}$ & $\mathbf{2}$ & $\mathbf{3}$ & $\mathbf{4}$ & $\mathbf{5}$ & $\mathbf{M}$ & SD \\
32Q & 5 & 1 & 23 & 82 & 71 & 4.170 & .8723 \\
33Q & 1 & 5 & 22 & 81 & 73 & 4.209 & .8008 \\
34Q & 4 & 2 & 43 & 63 & 70 & 4.060 & .9294 \\
35Q & 3 & 2 & 29 & 70 & 78 & 4.198 & .8632 \\
36Q & 6 & 8 & 46 & 64 & 58 & 3.879 & 1.017 \\
& & & & & & 4.103 & \\
\hline
\end{tabular}

$1=$ strongly disagree, $2=$ disagree, $3=$ neither agree nor disagree, $4=$ agree, $5=$ strongly agree, $\mathrm{M}=$ mean, $\mathrm{SD}=$ std.deviation

\section{Discussion}

The results of the study show that the pre-university students have a very high motivation towards learning English. Although the final findings seem to show that the pre-university students are instrumentally motivated $(M=4.318)$, their integrative motivation toward learning English is still high $(M=4.067)$. Instrumental motivation contains the purpose of gaining some social or economic incentive through L2 achievement, consequently, referring to a more functional reason for language learning. Integrative motivation is characterized by the learners' optimistic and positive attitudes towards the target language society and the aspiration to join together into the target language society (Gardner and Lambert, 1972). Knowing that the pre-university students' degree of instrumental motivation is higher than their integrative one could indicate that the students are trying to preserve their identity. Aspiration related to integrativeness might in one way or another affect their identity and their fear to be identified with western culture and values may be related to their sociocultural and religious affiliation. On the other hand, Instrumentality is found to be more prominent in some situations mainly where there appears to be little desire to integrate to the target language community.

That is to say, motivation could be perceived as the realization of human needs and human needs function as drives or incentives which shift one to a particular action. With respect to the second language learning, the second language learners needs to feel safe and confident that learning the target language and its culture doesn't negatively affect their own culture or language. Furthermore, openness in general and learning languages in particular needs a secure and an unstressful atmosphere to facilitate language acquisition. Admiration and social needs also indicate that the learner needs to be an educated person who is capable to communicate and assimilate with others by learning their language. Failure to suit students' needs is prone to hamper their risk-taking and motivation.

According to the data collected in the questionnaire, some of the de-motivating factors of the pre-university students as mentioned are:

- The students had a few opportunities to access English or to interact with others using English.

- The students have a few chances to communicate with English native speakers.

- The students are also not encouraged to speak English during their secondary studies and thus feel less confident to speak English.

- The students could not have enough chance to learn English, especially the most favored language skills as listening and speaking due to the limited instruction hours as the program for teaching English is not designed to do so.

- The students have to spend a lot of time and effort to learn the language and its grammar.

As a result, their English motivation would have probably decreased. It is true to say that to maintain the students' positive attitudes and motivation towards learning English and to ultimately improve their language proficiency, it could be useful for the universities to offer some intensive English courses such as English for Special Purposes (ESP) throughout the university years including the foundation level of study so that non-English major students could have constant contact with the target language. 
Basically, it is the role of the students as well as the language instructors to better understand the important role that the English language play as an international language as well as its effect so that they can better plan for the future consideration of the language and set all the necessary standards for it. For this reason, literary scholars must join the language instructors in a common concern for setting the goal. A few steps can be followed to be able to recognize the students' instrumental motivations. Among these steps are preparing exams that concentrate more on practical communication skills such as how to communicate with native speakers, how to interact with other people when traveling abroad or how to prepare themselves for job interview. On the other hand, several other activities can be done to raise the students' integrativeness and interests towards the target language community and culture (i.e., English) such as providing information on geographical, literature as well as the lifestyle of the English-speaking countries through visual, written and audio forms, or even organizing group sessions where students can share knowledge with other students who have been to English speaking countries.

Encouraging students to increase their knowledge and to continuously participant in class and in different lessons can sometimes assist them to enthusiastically see a rationale for improving their communication skills. Supporters of the integrative view suggest that language instructors should help students to realize that being proficient in another language other than their mother tongue can help them enhance their perception and understanding of other cultures.

\section{Conclusion}

The findings of the study portrayed a picture which establishes that pre-university students were instrumentally motivated but, however; their integrativeness is also high. This study also confirms the opinion of some researchers who believe that in foreign language settings students are instrumentally oriented. In other words, student motivation tends to be stronger when the learner has specific rather than general goals for language learning. However, taken together, findings from both qualitative and quantitative data of the present study give a consistent picture, that instrumental and integrative orientations, especially future career development, going abroad for further study, meeting more varied people from different cultural backgrounds and learning English in order to use the internet properly are very important for the students. It is clear that the teacher, the class atmosphere, the course content, materials and facilities, as well as personal characteristics of the student will have an influence on the individual's classroom learning motivation (Gardner, 2006). It is usually helpful for the teachers to touch base with their students from time to time to be sure that they don't lose track of their motivations towards learning the language while immersed in the day to day details of a language class. Yet, there is much work to be done before researchers, teachers, language instructors and language learners will fully understand motivation and all its aspects.

\section{References}

Ainol Madziah Zubairi, \& Isarji Hj Sarudin. (2009). Motivation to learn a foreign language in Malaysia. GEMA Online Journal of Language Studies, 9(2), 73-87.

Asmah, H. O. (1997). From imperialism to Malaysianisation: A discussion of the path taken by English towards becoming a Malaysian language. In Halimah Mohd Said, \& Ng. Keat Siew (Eds.), English is an Asian language in the Malaysian context (pp. 12-21).

Babaee, N. (2012). Motivation in Learning English as a Second Language: A Literature Review. Canadian Journal for New Scholars in Education, 4(1), 1-7.

Baker, S. C., \& MacIntyre, P. D. (2000). The role of gender and immersion in communication and second language orientations. Language Learning, 50, 311-341. http://dx.doi.org/10.1111/0023-8333.00119

Balkır, N. B., \& Topkaya, E. Z. (2009). Exploring the effects of learner training on motivation. Asian EFL Journal, 37, 1-40. Retrieved from http://www.asian-efl-journal.com/pta_July_2009_nb.php

Brown, J. D., \& Rodgers, T. S. (2002). Doing second language research. Oxford: Oxford University Press.

Chen, J. F., Warden, C. A., \& Chang, H. T. (2005). Motivators that do not motivate: The case of Chinese EFL learners and the influence of culture on motivation. TESOL Quarterly, 39(4), 609-633. http://dx.doi.org/10.2307/3588524

Clement, R., Dornyei, Z., \& Noels, K. A. (1994). Motivation, self-confidence, and group cohesion in the foreign language. Language Learning, 3, 417-448. http://dx.doi.org/10.1111/j.1467-1770.1994.tb01113.x

Dörnyei, Z. (1994). Motivation and motivating in the foreign language classroom. Modern Journal, 78, 273-84. Retrieved

http://seas3.elte.hu/coursematerial/RyanChristopher/Dornyei(1994)_Foreign_Language_Classroom.pdf 
Dörnyei, Z. (2001). Teaching and researching motivation. Harlow, England, United Kindgom: Longman.

Gardner, R. C. (1985). Social Psychology and Second Language Learning: The role of attitudes and motivation. London: Edward Arnold.

Gardner, R. C. (2004). Attitude Motivation Test Battery: International AMTB Research Project. Canada: The University of Western Ontario. Retrieved February 9, 2008, from http://publish.uwo.ca/ gardner/docs/englishamtb.pdf

Gardner, R. C. (2005). Integrative motivation and second language acquisition. Canadian Association of Applied Linguistics/Canadian Linguistics Association Plenary Talk, London, Ontario.

Gardner, R. C. (2006). The socio-educational model of second language acquisition: A research paradigm. EUROSLA Yearbook, 6, 237-260. http://dx.doi.org/10.1075/eurosla.6.14gar

Gardner, R., \& Lambert, W. (1972). Attitudes and Motivation in Second-Language Learning. Rowley, Ma.: Newbury House.

Gardner, R. C., \& MacIntyre, P. D. (1993). A student's contributions to second language learning: Part II: Affective variables. Language Teaching, 26, 1-11. http://dx.doi.org/10.1017/S0261444800000045

Gardner, R. C., Tremblay, P. F., \& Masgoret A. M. (1997). Towards a full model of second language learning: an empirical investigation. Modern Language Journal, 81, 344-362. http://dx.doi.org/10.1111/j.1540-4781.1997.tb05495.x

Gill, Saran K. (2002). International Communication: English Language Challenges for Malaysia. Serdang: Universiti Putra Malaysia Press.

Guilloteaux, M. J., \& Dörnyei, Z. (2008). Motivating language learners: A classroom-oriented investigation of the effects of motivational strategies on student motivation. TESOL Quarterly, 42, 55-77.

Lamb, M. (2007). The impact of school on EFL learning motivation: An Indonesian case study. TESOL Quarterly, 41(4), 757-780.

Liu, M. (2007). Chinese students' motivation to learn English at the tertiary level. Asian EFL Journal, 9(1), 126-146. Retrieved from http://www.asian-efl-journal.com/March_2007_EBook.pdf

Mansor, D. (1997). Education policy for English in Malaysia. In Halimah Mohd Said, \& Ng. Keat Siew (Eds.), English is an Asian language in the Malaysian context (pp. 22-25). Kuala Lumpur: Modern Language Association, Malaysia.

Masgoret, A. M., Bernaus, M., \& Gardner, R. C. (2001). Examining the role of attitudes and motivation outside of the formal classroom: A test of the mini-AMTB for children. In Z. Dornyei, \& R. Schmidt (Eds.), Motivation and second language acquisition (pp. 281-295). Second Language Teaching \& Curriculum Center. Honolulu, HI: The University of Hawaii.

Masgoret, A. M., \& Gardner, R. C. (2003). Attitudes, Motivation and Second Language Learning: A Meta-Analysis of Studies Conducted by Gardner and Associates. Language Learning, 53, 123-163. http://dx.doi.org/10.1111/1467-9922.00212

Melendy, G. (2008). Motivating writers: The power of choice. The Asian EFL Journal, 10(3), 187-198. Retrieved from http://www.asian-efl-journal.com/September_08_gm.php

Rahman, S. (2005). Orientations and motivation in English language learning: A study of Bangladeshi students at undergraduate level. Asian EFL Journal, 7(1), 1-25. Retrieved from http://www.asian-efl-journal.com/march_05_sr.pdf

Samsiah Bidin, Kamaruzaman Jusoff, Nurazila Abdul Aziz, Musdiana Mohammad Salleh, \& Taniza Tajudin. (2009). Motivation and attitude in learning English among UiTM students in the northern region of Malaysia. English Language Teaching, 2(2), 16-20.

Takase, A. (2007). Japanese high school students' motivation for extensive L2 reading. Reading in a Foreign Language, 19(1), 1-18.

Wang, X. (2007). Three ways to motivate Chinese students in EFL listening classes. Asian EFL Journal, 37. Retrieved from http://www.asian-efl-journal.com/pta_Jan_07_xw.pdf

Thang, S. M. (2004). Learning English in multicultural Malaysia: Are learners motivated? Journal of Language and Learning, 2(2). 
Wei, M. (2007). The interrelatedness of affective factors in EFL learning: An examination of motivational patterns in relation to anxiety in China. TESL-EJ, 11(1), 1-23. Retrieved from http://tesl-ej.org/ej41/a2.pdf

Winke, Paula M. (2005). Promoting motivation in the foreign language classroom. Clear News, 9, 1-5. Retrieved from http://clear.msu.edu/clear/newsletter/fall2005.pdf

Wu Man-fat, M. (2007). The relationships between the use of metacognitive language-learning strategies and language-learning motivation among Chinese-speaking ESL learners at a vocational education institute in Hong Kong. Asian EFL Journal, 9(3), 93-117. Retrieved from http://www.asian-efl-journal.com/September_2007_EBook_editions.pdf

Wu, W. C. V., \& Wu, P. H. N. (2008). Creating and authentic EFL learning environment to enhance student motivation to study English. Asian EFL Journal, 10(4), 211-226. Retrieved from www.asian-efl-journal.com/December_2008_EBook.pdf

Yihong, G., Yuan, Z., Ying, C., \& Yan, Z. (2007). Relationship between English learning motivation types and self-identity changes among Chinese students. TESOL Quarterly, 41(1), 133-155. 